\title{
Effects of Nitrogen Levels on Anatomy, Growth, and Chlorophyll Content in Sunflower (Helianthus annuus L.) Leaves
}

\author{
Santosh Kumari ${ }^{1}$ \\ ${ }^{1}$ Division of Plant Physiology, Indian Agricultural Research Institute, New Delhi, India \\ Correspondence: Santosh Kumari, Division of Plant Physiology, Indian Agricultural Research Institute, New \\ Delhi 110012, India. Tel: 91-11-6542-4724. E-mail: smile.santosh.kumari@gmail.com
}

Received: April 23, 2017

Accepted: June 26, $2017 \quad$ Online Published: July 15, 2017

doi:10.5539/jas.v9n8p208

URL: https://doi.org/10.5539/jas.v9n8p208

\begin{abstract}
Nitrogen nutrition strongly affected the individual leaf expansion, formation and development of palisade and spongy cells, chloroplast membrane organization and number of grana thylakoids, chlorophyll a, and b proportion, chloroplast length and width, epidermal cell division and expansion in sunflower (Helianthus annuus L.) leaves. Nitrogen levels remarkably affected the development of phloem transfer cells, thereby loading and unloading capacity of phloem. Nitrogen nutrition environment exert developmental control on phloem size via cytokinin production by increased root growth in sunflower.
\end{abstract}

Keywords: anatomy, chlorophyll content, chloroplast, epidermis, grana thylakoid, leaf expansion, nitrogen level, palisade cell, spongy cell, sunflower, transfer cell

\section{Introduction}

Effects of nitrogen on leaf number, individual leaf area, leaf area per plant, leaf area index, and photosynthetic rate per unit leaf area, biomass production and yield have been documented (Steer \& Hocking, 1983; Milford et al., 1985; Vos \& Biemond, 1992; Trápani \& Hall, 1996; Gasal \& Lemaire, 2002). Little emphasis has been placed on the study of optimization of nitrogen requirements for leaf growth to avoid crop lodging and loss of nitrogen fertilizer in excess vegetative crop growth.

Leaves contain the complex photosynthetic machinery capable of capturing light and using the energy for the reductive assimilation of carbon dioxide $\left(\mathrm{CO}_{2}\right)$ and nitrate ions with the formation of carbohydrates and amino acids, respectively. Roots capture water and mineral nutrients which are required for metabolism. The carbon (C) and nitrogen $(\mathrm{N})$ assimilates produced are exported to the growing regions of the plant where they are incorporated into new vegetative cells and tissues, giving rise to reproductive organs and seed, thus completing the growth cycle (Ourry et al., 2001). The processes and fluxes of $\mathrm{N}$ - and $\mathrm{C}$-assimilates are dependent upon the supply of resources from, and conditions in the environment (Paul \& Foyer, 2001; Lawlor, 1994). Current knowledge of how plants metabolize $\mathrm{N}$ is adequate although improvements in understanding the system as a whole in order to achieve optimum production with less $\mathrm{N}$ and other resources would be desirable. Nitrogen application enhances biomass production via effects on leaf area and leaf number. The photosynthetic rate per unit of leaf area is affected by nitrogen partitioning in thylakoid membranes, enzymes of photosynthetic carbon reduction cycle, nitrogen assimilation (Millard \& Catt, 1988; Farquhar et al., 1980; Kumari, 2011) and prolongation of leaf area duration (Pearman et al., 1979). However, few studies have addressed the partitioning of nitrogen in different cell layers of photosynthetic surface area, sensitivity and mechanism of leaf area development (Radin \& Boyer, 1982; MacAdam et al., 1989). Morphological, cellular and metabolic investigations into leaf growth are used to build up the complete picture of the events that take place from the initiation of a leaf to its eventual death (Maksymowych, 1973). Sunflower is an important oil seed crop worldwide and for biodiesel in USA. The adverse environmental conditions abruptly trigger leaf senescence and limit crop production. Sunflower is also a model plant with opposite and alternate phyllotaxy to study the leaf development. Therefore, in this investigation, effect of different nitrogen levels was studied on anatomy, growth and chlorophyll contents in sunflower leaves grown in net house under natural environmental conditions. 


\section{Materials and Methods}

Sunflower genotype Morden (dwarf) was grown in earthen pots $(30 \mathrm{~cm} \times 30 \mathrm{~cm}$ size) filled with field soil and manure in $6: 2$ under natural conditions (maximum temperature $35 \pm 2{ }^{\circ} \mathrm{C}$ and minimum temperature $28 \pm 2{ }^{\circ} \mathrm{C}$ ) in July to October. Fifty pots were used for each treatment and one plant was maintained after thinning at two leaf stage in the center of each pot. Nitrogen was applied at this stage in water as urea at the rate of $0,60,90$ and 120 $\mathrm{kg} \mathrm{N} \mathrm{ha}{ }^{-1}$ maintaining the recommended ratio of NPK as 120:150: $45 \mathrm{~kg} \mathrm{ha}^{-1}$ for sunflower cultivation. The plants were monitored daily to meet the water demand. The plant protection measures were taken to keep the net house free from pests. $5^{\text {th }}$ and $8^{\text {th }}$ opposite leaves on the node number five and six from the bottom were used for measurement of leaf length and width, 30 days after sowing (DAS). Fully expanded Fourth leaf from the top ( $9^{\text {th }}$ from bottom) was used for anatomical (40 days after sowing), protein and chlorophyll contents analysis (42 and 60 days after sowing) under different levels of nitrogen supply. Rate of photosynthesis was recorded 15 days after nitrogen application by Infra-Red Gas analyzer (ADC 225MK3) in sunflower leaves without nitrogen and with $90 \mathrm{~kg} \mathrm{~N} \mathrm{ha}^{-1}$. A separate experiment was conducted by sowing seeds on $2^{\text {nd }}$ May and growing sunflower (Morden) plants under high radiation and temperature condition using the same growing medium and treatments. Fourth leaf from the top was used for the analysis of pigment profile by TLC at head initiation stage.

\subsection{Light and Electron Microscope Measurements}

Fourth fully expanded leaf sections $(1 \mathrm{~mm})$ were fixed overnight at $4{ }^{\circ} \mathrm{C}$ in $2 \%(\mathrm{v} / \mathrm{v})$ para formaldehyde- $2 \%(\mathrm{v} / \mathrm{v})$ glutaraldehyde solution in $0.1 \mathrm{M}$ phosphate buffer $(\mathrm{pH} 7.2)$, post fixed in $2 \%(\mathrm{w} / \mathrm{v})$ osmium tetra oxide $\left(\mathrm{OsO}_{4}\right)$, embedded in a mixture of Epon and Araldite after a standard dehydration procedure. Semi-thin leaf cross-sections were used for light microscopy or tissue identification prior to Transmission electron microscopy. Electron microscopy sections were stained with $1 \%(\mathrm{w} / \mathrm{v})$ Toluidine Blue O in $1 \%(\mathrm{w} / \mathrm{v})$ sodium borate. These sections were analysed under light microscope (Nikon, Tokyo, Japan) prior to ultra-structural examination. These images were analysed for surface area of different cell layers downloading Image J software available on Google. Ultra-thin sections were collected on copper grids with a support film of formvar and carbon. The sections were counterstained in $2 \%$ uranyl acetate for $15 \mathrm{~min}$ followed by lead citrate solution for $3 \mathrm{~min}$ and examined with a Philips CM-10 electron microscope (Netherland) at $60 \mathrm{KV}$.

Fresh leaf tissue after standard dehydration process in ethanol (30-100\%) and critical dried point in liquid carbon dioxide was mounted on the metal stubs with a paste of colloidal silver and coated with a thin film of gold in a sputtering coater and examined under LEO 435 VP scanning electron microscope at All India Institute of Medical Sciences, New Delhi, India.

\subsection{Total Pigments and Soluble Protein Estimation}

Chlorophyll extraction was done in $80 \%$ ethanol and chlorophyll a and b were calculated as described by Arnon (1949). Protein extraction was done in the residue left after chlorophyll extraction by hydrolysis with $5 \mathrm{ml}$ of $1 \mathrm{~N}$ $\mathrm{NaOH}$ for $24 \mathrm{~h}$. Thereafter, it was centrifuged at $5000 \mathrm{rpm}$ for $20 \mathrm{~min}$. The supernatants were used for protein estimation (Lowry et al., 1951). Leaf pigments were extracted from fresh fourth fully expanded leaf by addition of $100 \%$ acetone to the tissue ground with liquid nitrogen (Lichtenthaler, 1987) in an experiment under high temperature and radiation. After centrifugation, $250 \mu \mathrm{l}$ of the supernatant were spotted on precoated- silica gel 60 F254 TLC plate (Merck- Germany) and separated with petroleum ether:isopropanol: $\mathrm{H}_{2} \mathrm{O}$ (100:15:0.25) as running solvent.

\section{Results}

\subsection{Leaf Enlargement}

Length and width measurements were started when leaf length was $1 \mathrm{~cm}$ in control leaf on $3^{\text {rd }}$ day of leaf appearance. Long-term leaf enlargement was increased by nitrogen nutrition (Figures 1 and 1A). Short-term leaf elongation $\times$ expansion was faster under $\mathrm{N}$ starvation (control) $29.04 \mathrm{~cm}^{2}>$ in $60 \mathrm{~kg} \mathrm{~N} \mathrm{ha}{ }^{-1}\left(9.46 \mathrm{~cm}^{2}\right)>120 \mathrm{~kg}$ $\mathrm{N} \mathrm{ha}^{-1}$ leaves $\left(5.55 \mathrm{~cm}^{2}\right)$ of sunflower. On day $9^{\text {th }}$ leaf elongation $\mathrm{x}$ expansion were $61.75 \mathrm{~cm}^{2}$ in control, 72.76 $\mathrm{cm}^{2}$ in $60 \mathrm{~kg} \mathrm{~N} \mathrm{ha}^{-1}$ and $78.28 \mathrm{~cm}^{2}$ in $120 \mathrm{~kg} \mathrm{~N} \mathrm{ha}^{-1}$. Leaves were fully expanded at this stage and no change was observed on $11^{\text {th }}$ day of measurements. Fresh mass per unit leaf area of upper leaves was $0.027 \mathrm{mg} \mathrm{cm}^{-2}$ in control $<0.035 \mathrm{mg} \mathrm{cm}^{-2}$ in $60 \mathrm{~kg} \mathrm{~N} \mathrm{ha}^{-1}<0.038 \mathrm{mg} \mathrm{cm}^{-2}$ in $120 \mathrm{~kg} \mathrm{~N} \mathrm{ha}^{-1}$ after 45 days of sowing. Number of Leaves was 30, 28, 26 and 25 under 120,90, $60 \mathrm{~kg} \mathrm{~N} \mathrm{ha}^{-1}$ and control plants, respectively. 


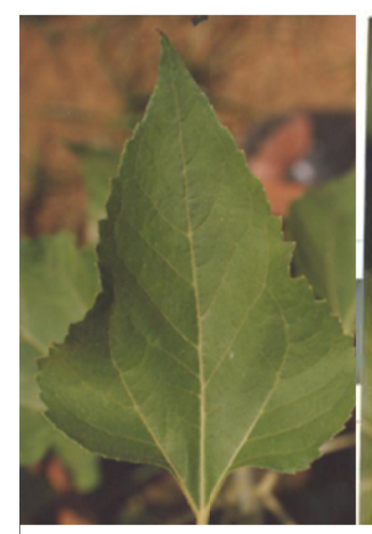

$120 \mathrm{~kg} \mathrm{~N} \mathrm{ha}^{-1}$

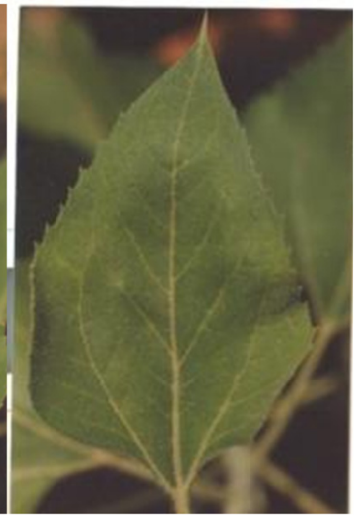

$90 \mathrm{~kg} \mathrm{~N} \mathrm{ha}{ }^{-1}$

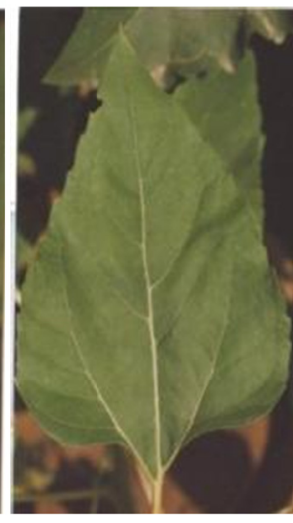

$60 \mathrm{~kg} \mathrm{~N} \mathrm{ha}^{-1}$

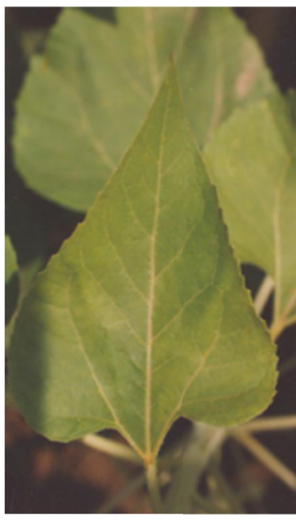

Control

Figure 1. Leaf size (area), shape and color of sunflower leaf (fully expanded, $4^{\text {th }}$ from top) under different levels of nitrogen

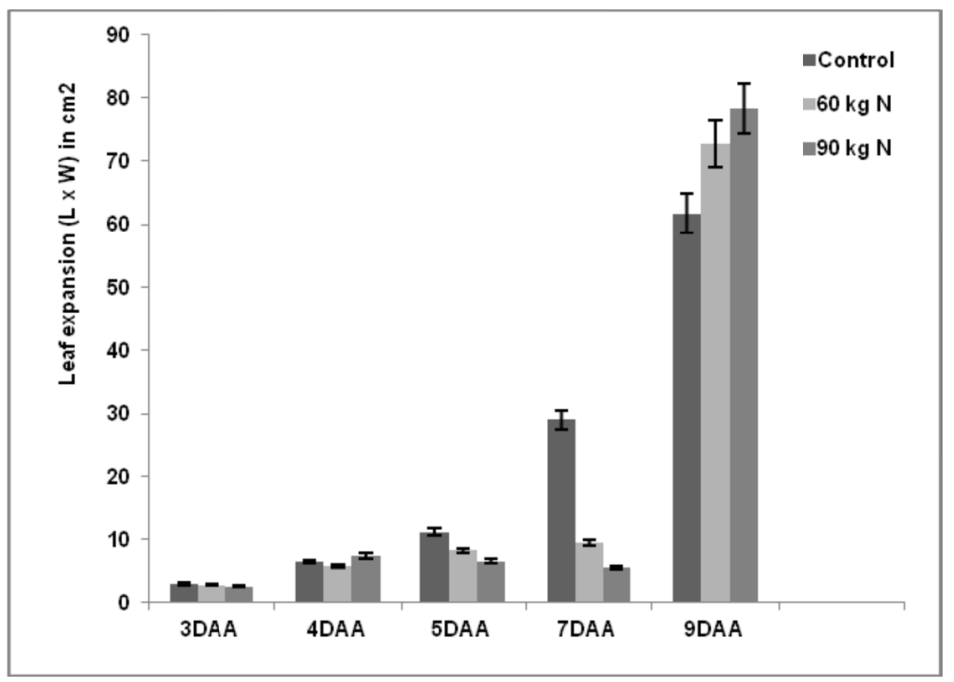

Figure 1A. Leaf expansion (length $\times$ width $=\mathrm{cm}^{2}$ ) at different days after appearance of $1 \mathrm{~cm}$ length of sunflower (Morden) leaves grown under different levels of nitrogen

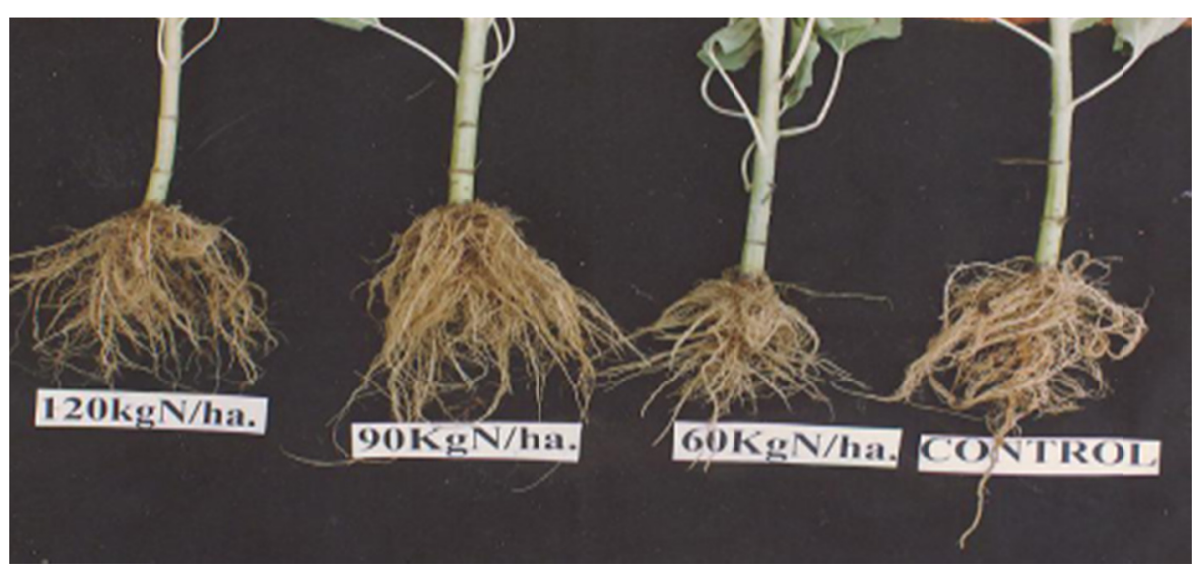

Figure 1B. Root length, biomass and stem thickness of sunflower under different levels of nitrogen 


\subsection{Leaf Anatomy}

Figure 2 reveals that nitrogen supply ( 60 and $\left.120 \mathrm{~kg} \mathrm{~N} \mathrm{ha}^{-1}\right)$ increased the length of epidermal cells especially in upper epidermis when compared with that of control leaf. Number of photosynthetic cells i.e. palisades and spongy parenchyma were reduced in the process of leaf elongation $\left(60 \mathrm{~kg} \mathrm{~N} \mathrm{ha}^{-1}\right)$. While airspace among palisade cells and air cavities under stomata were increased under this treatment.

Reduction in size of epidermal cells was associated with nitrogen starvation and with increased number of cells in lower epidermis especially under 90 and $120 \mathrm{~kg} \mathrm{~N} \mathrm{ha}^{-1}$. Number of spongy cells and palisade cells in the second layer $\left(90 \mathrm{~kg} \mathrm{~N} \mathrm{ha}^{-1}\right)$ were increased in photosynthetic tissue (Figures $2 \mathrm{~A}$ and $\left.2(B)\right)$ under nitrogen supply.

$\boldsymbol{A}$

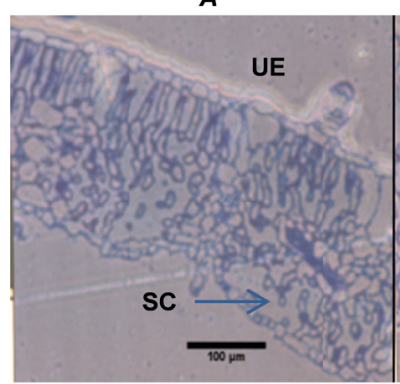

$120 \mathrm{~kg} \mathrm{~N} \mathrm{ha}^{-1}$
$B$

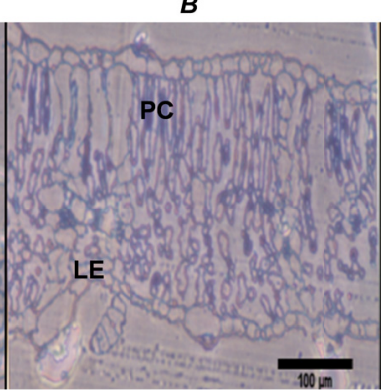

$90 \mathrm{~kg} \mathrm{~N} \mathrm{ha}^{-1}$

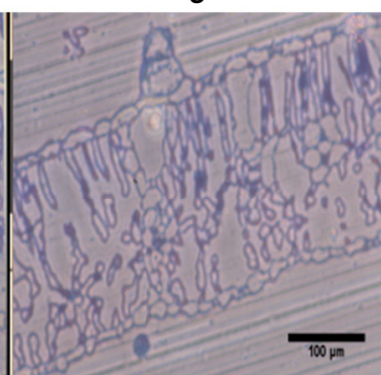

$60 \mathrm{~kg} \mathrm{~N} \mathrm{ha}^{-1}$
D

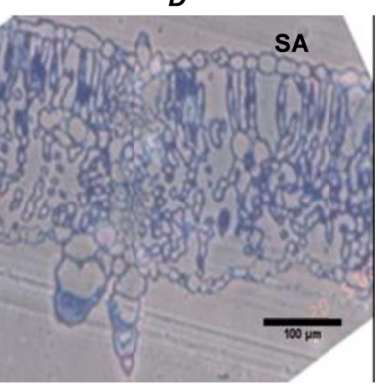

Control

E

$\boldsymbol{F}$

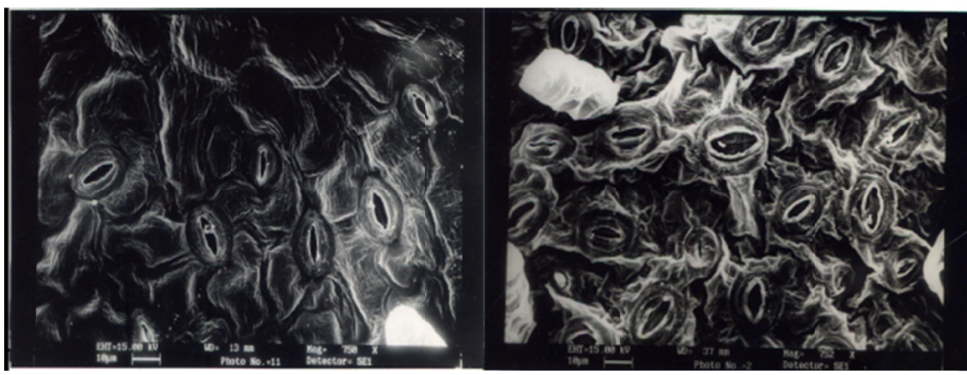

Control

$90 \mathrm{~kg} \mathrm{~N} \mathrm{ha}^{-1}$

Figure 2. Anatomy and stomatal aperture of sunflower leaves under different levels of nitrogen

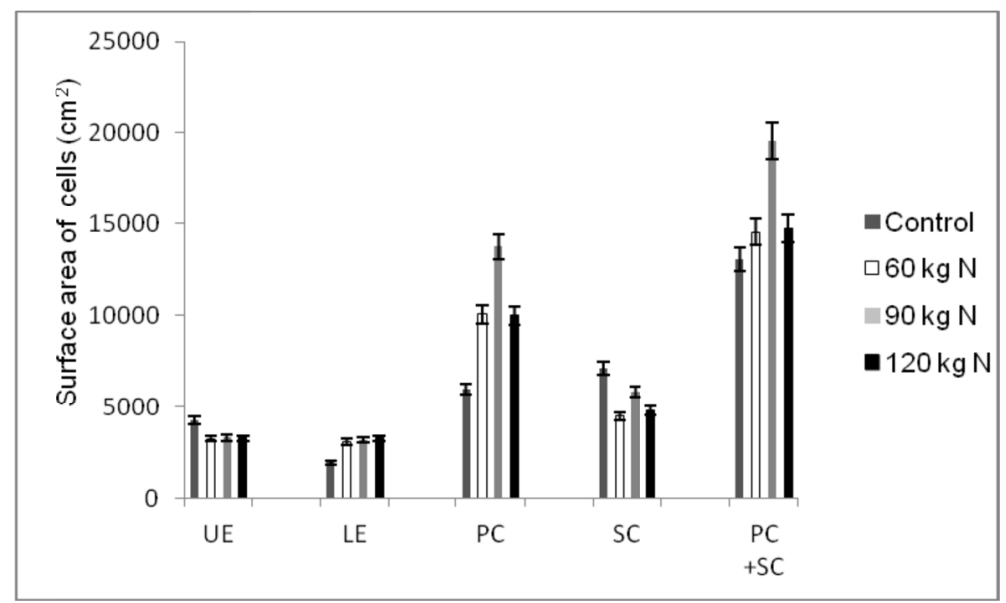

Figure 2A. Surface areas of different types of cells (upper epidermis, lower epidermis, palisade cells, spongy cells and palisade + spongy cells) from light micrographs of sunflower leaves under different levels of nitrogen 

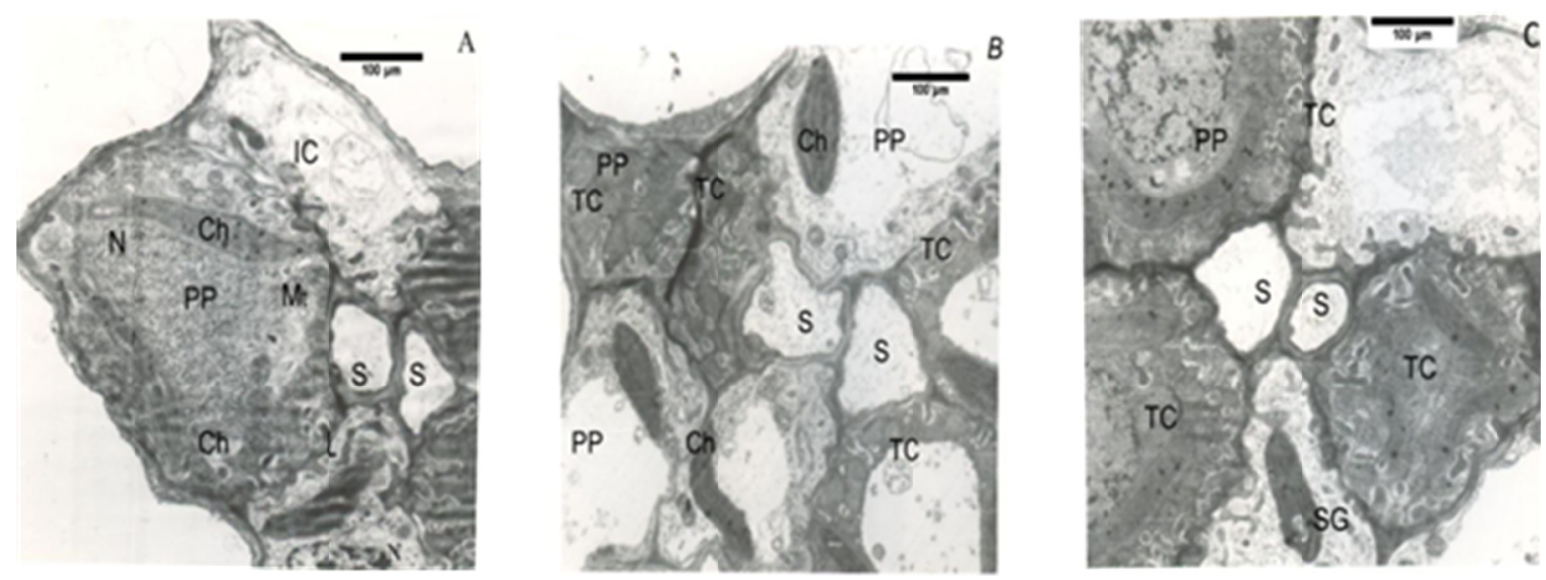

Figure 3. Transfer cells and sieve elements in vascular bundle of sunflower leaves under different levels of nitrogen. (A) Control, (B) $90 \mathrm{~kg} \mathrm{~N} \mathrm{ha}^{-1}$, (C) $120 \mathrm{~kg} \mathrm{~N}$ ha $^{-1}$, (N) nucleus, (Ch) chloroplast, (Mt) mitochondria, (S) sieve element, (PP) phloem parenchyma, (SG) starch grain, (TC) transfer cell

Phloem and xylem parenchyma cells were enlarged with increasing nitrogen levels i.e. 0,90 and $120 \mathrm{~kg} \mathrm{~N} \mathrm{ha}^{-1}$. Magnificent increase in the wall ingrowths and formation of two types of transfer cells from phloem and xylem parenchyma cells of minor veins of sunflower leaf and their maturation stages are revealed in Figures 3A, 3B and 3C. Phloem cells with nucleus and chloroplast containing starch grain $\left(120 \mathrm{~kg} \mathrm{~N} \mathrm{ha}^{-1}\right)$ and xylem transfer cells are evident around the sieve elements under nitrogen supply.

Chloroplast width, grana width and number were more in 90 and $120 \mathrm{~kg} \mathrm{~N}^{-1}$ (Figures 4B and 4E) than in 60 $\mathrm{kg} \mathrm{N} \mathrm{ha}^{-1}$ (Figures 4A and 4C). Degenerating mitochondria, appearance of liposomes in the cytoplasm and its orientation with nucleus, plastoglobulii in chloroplast are the indicators of early onset and progression of senescence under control than different levels of nitrogen (Figures 4C, 4D, 4E, and 4F). Chloroplasts of different dimensions were aligned with cell walls in all treatments but a few were seen accumulated at the lower end of palisade cells in $120 \mathrm{~kg} \mathrm{~N} \mathrm{ha}^{-1}$, filling the cytoplasmic space. 


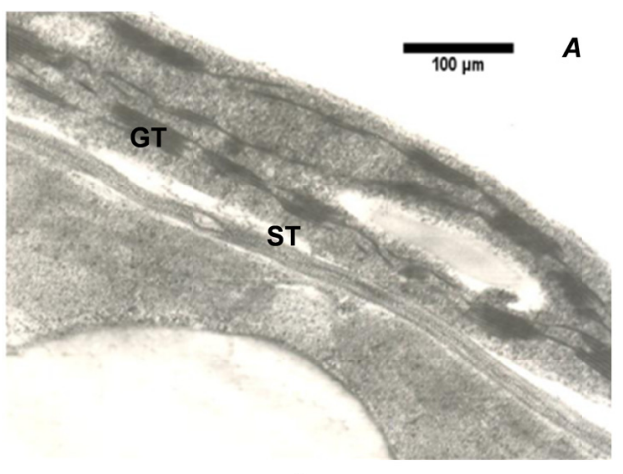

$60 \mathrm{~kg} \mathrm{Nha}^{-1}(11500 \mathrm{x})$

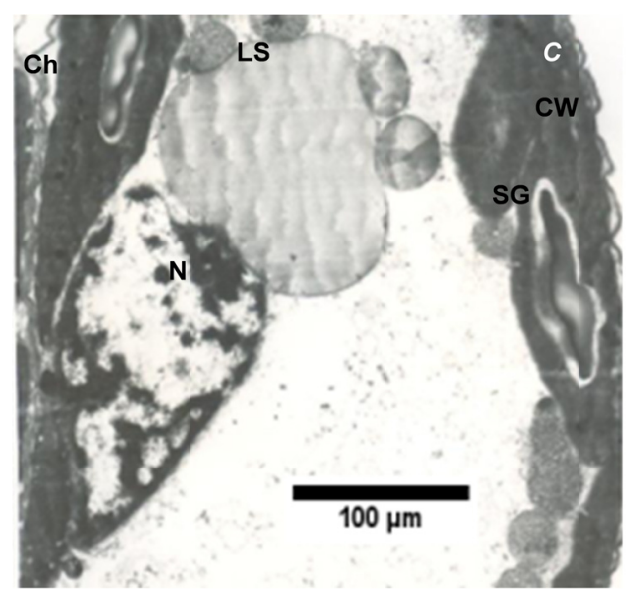

Control (6300x)

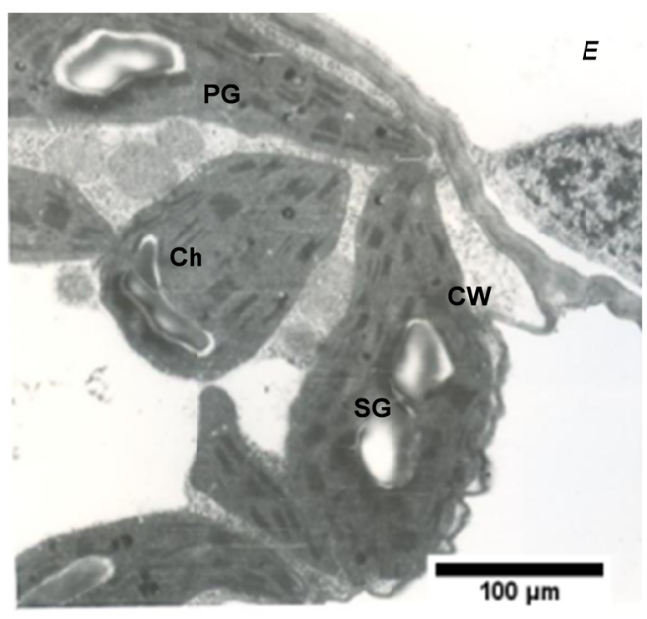

$120 \mathrm{~kg} \mathrm{~N}^{-1}{ }^{-1}(3400 \mathrm{x})$

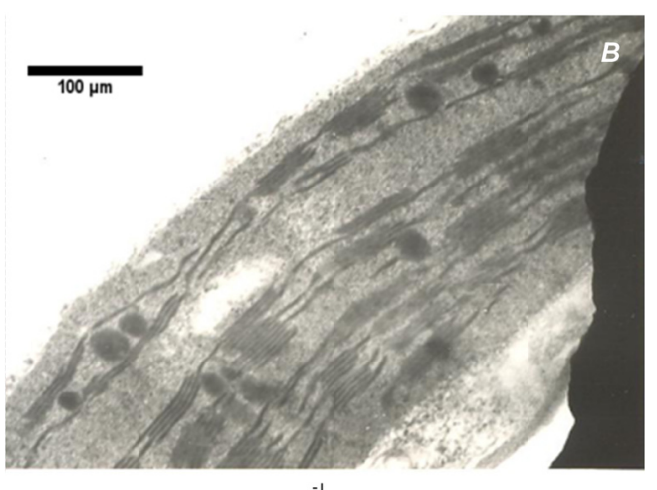

$90 \mathrm{~kg} \mathrm{~N} \mathrm{ha}^{-1}(11500 \mathrm{x})$

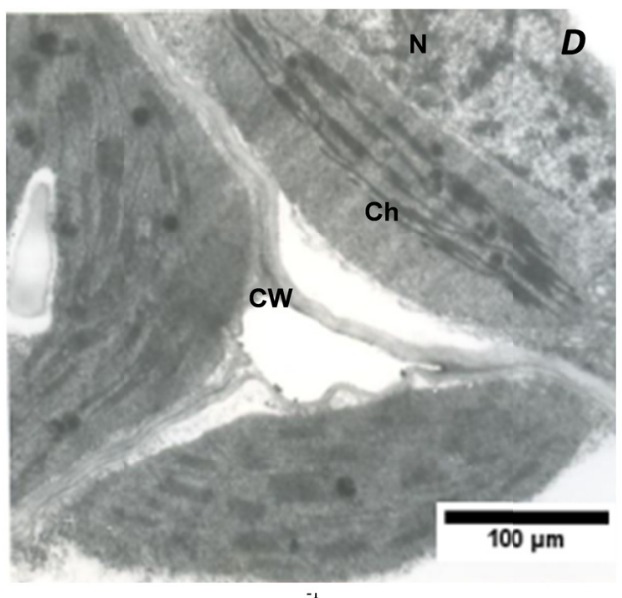

$90 \mathrm{~kg} \mathrm{~N}$ ha $(3400 \mathrm{x})$

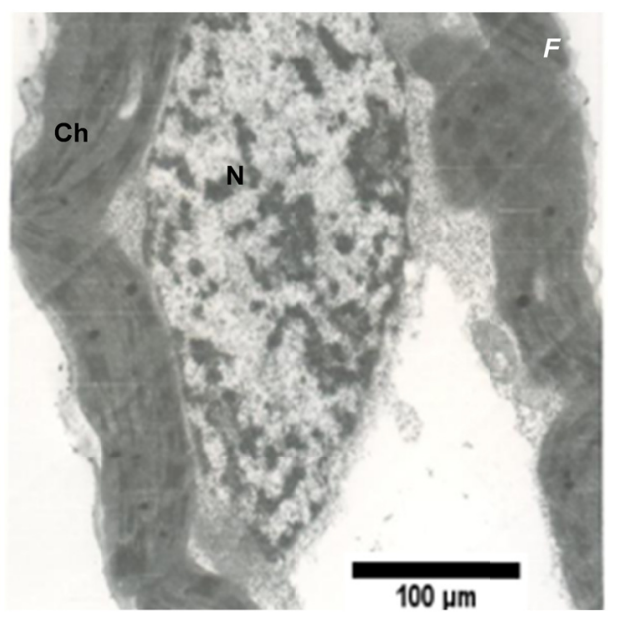

$90 \mathrm{~kg} \mathrm{~N} \mathrm{ha}^{-1}(4400 \mathrm{x})$

Figure 4. Electron micrograph of palisade cells and chloroplast ultrastructure under different levels of nitrogen. Chloroplast (Ch), grana thylakoid (GT), stroma thylakoid (ST), starch grain (SG), plastoglobulii (PG), cell wall (CW), liposome (LS), and nucleus (N) 
$\boldsymbol{A}$

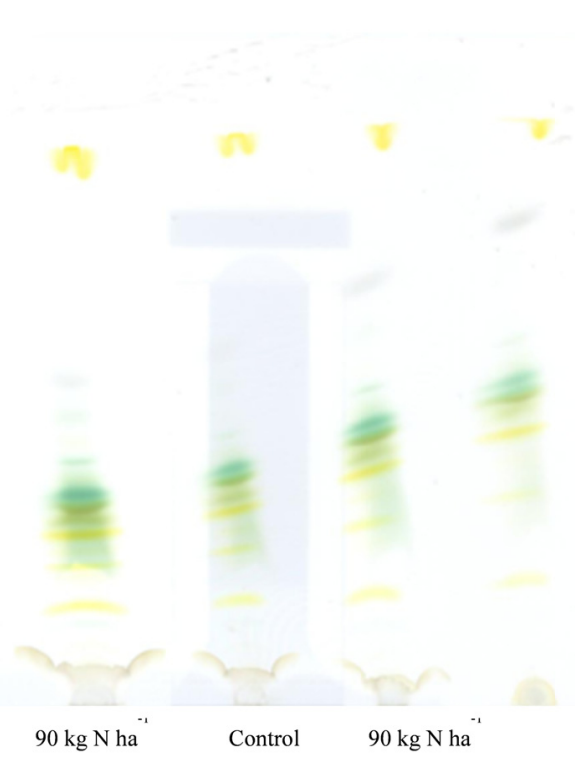

$B$

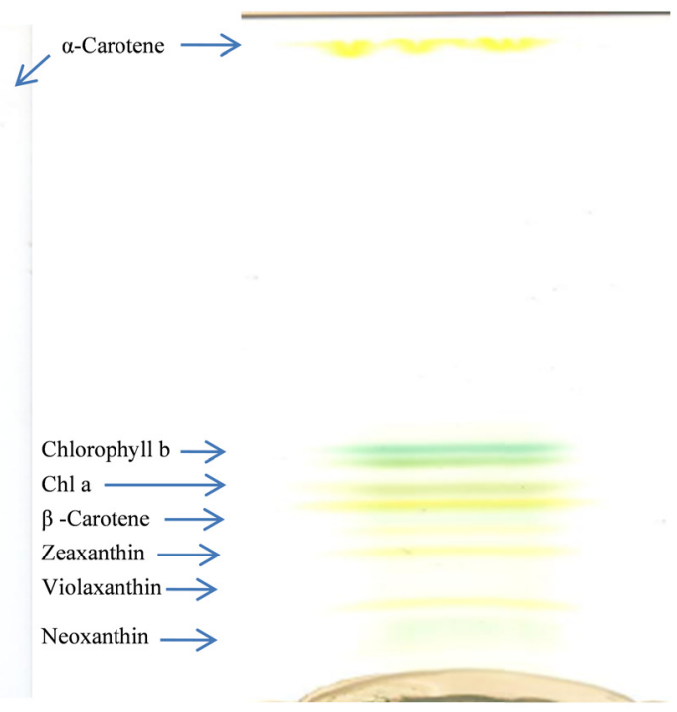

Figure 5. Pigment profile of sunflower leaves under different levels of nitrogen

\subsection{Total Pigments and Chlorophyll}

Chlorophyll a was increased with increased availability of nitrogen while chlorophyll b was decreased on per unit fresh mass basis. Total chlorophyll contents were higher with nitrogen nutrition in fully expanded leaves (42 DAS) of sunflower (Figure 1). Total chlorophyll contents of these leaves were depleted faster at flowering stage (60 DAS) under higher supply of nitrogen. The symptoms of senescence appeared earlier under control condition in electron micrographs in terms of chloroplast degradation and liposome formation but total chlorophyll were higher at flowering stage when measured by spectrophotometer (Table 1) and compared with 60 and $120 \mathrm{~kg} \mathrm{~N}$ $\mathrm{ha}^{-1}$.

Table 1. Chlorophyll contents ( $\left.\mathrm{mg} \mathrm{g}^{-1} \mathrm{FM}\right)$ and total soluble protein content $\left(\mathrm{mg} \mathrm{g}^{-1} \mathrm{FM}\right)$ in $4^{\text {th }}$ fully expanded leaf of sunflower at head initiation and flowering stage under different levels of nitrogen

\begin{tabular}{|c|c|c|c|c|c|c|c|c|c|c|}
\hline \multirow{2}{*}{ Treatment } & \multicolumn{4}{|c|}{ Head initiation (42 DAS) } & \multicolumn{4}{|c|}{ Flowering (60 DAS) } & \multicolumn{2}{|c|}{ Total soluble protein } \\
\hline & Chl a & Chl b & $\mathrm{Chl} \mathrm{a/b}$ & Total Chl & Chl a & Chl b & $\mathrm{Chl} \mathrm{a/b}$ & Total Chl & 42 DAS & 60 DAS \\
\hline Control & 1.152 & 0.953 & 1.209 & 2.105 & 4.654 & 5.116 & 0.910 & 9.770 & 26.75 & 40.00 \\
\hline $60 \mathrm{~kg} \mathrm{~N} \mathrm{ha}^{-1}$ & 2.121 & 0.651 & 3.257 & 2.772 & 4.174 & 5.575 & 0.749 & 9.749 & 28.00 & 43.00 \\
\hline $120 \mathrm{~kg} \mathrm{~N} \mathrm{ha}^{-1}$ & 2.223 & 0.382 & 5.820 & 2.605 & 4.635 & 4.872 & 0.951 & 9.507 & 31.25 & 60.00 \\
\hline $\mathrm{CD}$ at $5 \%$ & 0.130 & 0.036 & 0.060 & 0.165 & 0.065 & 0.033 & 0.013 & 0.165 & 0.593 & 2.564 \\
\hline
\end{tabular}

\subsection{Total Soluble Protein}

Total soluble proteins were higher at both stages of estimation (42 DAS and 60 DAS) with increased supply of nitrogen in sunflower leaves (Table 1).

\subsection{Statistical Analysis}

Analysis of data was done by analysis of variance (ANOVA) of single factor using MStat software.

\section{Discussion}

This study reveals that variations in leaf expansion (Figure 1) affected maximum leaf area of the leaf and total leaf area of sunflower plant under different levels of nitrogen. Figure 1A shows that leaf area achieved by leaves under control, $60 \mathrm{~kg} \mathrm{~N} \mathrm{ha}^{-1}$ and $90 \mathrm{~kg} \mathrm{~N} \mathrm{ha}^{-1}$ was at par till $5^{\text {th }}$ day after appearance. At $7^{\text {th }}$ day after leaf appearance, leaf expansion (length $\times$ width) in terms of leaf area achieved was significantly higher in control plants. Thereafter, leaf expansion shot up with increasing supply of nitrogen $\left(90 \mathrm{~kg} \mathrm{~N} \mathrm{ha}^{-1}>60 \mathrm{~kg} \mathrm{~N} \mathrm{ha}^{-1}>\right.$ control). Analysis of anatomical data along with increase in length and width separately indicates that at the 
initial phases of growth cell division and expansion in the epidermal cells were linked with leaf expansion rate rather than the duration of the expansion under different levels of nitrogen. Final leaf size is achieved by expansion of epidermal cells indicated by $60 \mathrm{~kg} \mathrm{~N} \mathrm{ha}^{-1}$ and $120 \mathrm{~kg} \mathrm{~N} \mathrm{ha}^{-1}$ and by division and expansion (MacAdam et al., 1989) of both epidermal and palisade cells in $90 \mathrm{~kg} \mathrm{~N} \mathrm{ha}^{-1}$ consequently forming two layers those are achieved earlier in control on $5^{\text {th }}$ day. The leaf area $(1 \times \mathrm{w})$ growth is faster in control and also indicates cessation of cell division activity in all layers of different types of cells ensuring minimum leaf area at $5^{\text {th }}$ day after leaf appearance. Variations at the basal region or 70 percent leaf area in shape of lamina lobes and texture are also indicators of anatomical alterations (Figure 1).

Our anatomical data clearly display the altered arrangement of palisade and spongy cells, larger air cavities, longer upper and lower epidermal cells under $60 \mathrm{~kg} \mathrm{~N} \mathrm{ha}^{-1}$ when compared with $90 \mathrm{~kg} \mathrm{~N} \mathrm{ha}^{-1}$ and control. Furthermore, chloroplast ultrastructure comparisons in these two treatments reveal the difference in shape, length, width, number and electron density and width of grana and stroma thylakoids. Higher number of grana and wider chloroplasts justifies the investment of adequate supply of nitrogen and increase in specific leaf nitrogen with two layers of palisade cells and increased number of spongy cells accommodating more chloroplasts and Ribulose bisphosphate carboxylase in their stroma. Furthermore, the spatial segregation of PSI/LHCI exclusively in nonappressed regions of thylakoids and PSII/LHCII in the appressed region (Figures 4(A) and (B)) of grana membranes and unequal number means that cyclic and noncyclic photophosphorylation can occur more or less simultaneously to meet the biosynthetic energy requirements within the chloroplasts and of photosynthesis in the leaves under varying supply of nitrogen (Khamis et al., 1990).

Cell division activity was enhanced further in the lower epidermis under nitrogen treatments. Cell maturation of vascular bundle was earlier (Figure 3(A)) in control than $90 \mathrm{~kg} \mathrm{~N} \mathrm{ha}^{-1}$ (B) and $120 \mathrm{~kg} \mathrm{~N} \mathrm{ha}^{-1}$ (C) where labyrinth formation is more in transfer cells and sieve elements are not empty (dead). Presence of starch grain in chloroplast of phloem parenchyma (C) indicates the higher availability of photo assimilates with increased levels of nitrogen $\left(8.54 \mu\right.$ moles $\mathrm{CO}_{2} \mathrm{~m}^{-2} \mathrm{~s}^{-1}$ in control vs. $8.99 \mu$ moles $\mathrm{CO}_{2} \mathrm{~m}^{-2} \mathrm{~s}^{-1}$ in $90 \mathrm{~kg} \mathrm{~N}^{-1)}$ in sunflower leaves. Cell wall surface area in ultrastructure of sieve elements indicates that the water relation was changed by nitrogen nutrition. Shape of subsidiary cells was very interesting feature to notice with closed and partially open stomata in control, 60, 120 and $90 \mathrm{~kg} \mathrm{~N} \mathrm{ha}^{-1}$, respectively (Figures 2(A), 2(B), 2(C), and 2(D)). Leaf number was also increased by nitrogen supply viz; 25 in control, 26, 28 and 30 in 60,90 and $120 \mathrm{~kg} \mathrm{~N}^{-1}$, respectively. Stomatal conductance was reduced as displayed (Figures 2(E) and 2(F)) with nitrogen starvation under scanning electron microscopy (Hunt et al., 1985; Chapin et al., 1988; Hak et al., 1993) with significant decrease in photosynthetic carbon dioxide assimilation (Sage \& Pearcy, 1987; Evans \& Terashima, 1987; Sugiharto et al., 1990).

Further, our data on transfer cell (Figures 3(A), 3(B), and 3(C)) confirms the increase in translocation from mesophyll cell to the sink tissue (emerging leaves and growing head) of sunflower. Adenosine Tri-phosphatase (ATPases) located in plasma membrane folding of transfer cells lead to increase ion uptake for increased growth with higher supply of nitrogen. Phloem parenchyma transfer cells/companion cells of leaf minor veins form wall ingrowths which are involved in phloem loading (Haritatos et al., 2000) by facilitating apoplasmic unloading of sucrose. In general, transfer cells are located at strategically important positions for nutrient acquisition and exchange (Gunnino \& Pate, 1969), such as symplasmic/apoplasmic interfaces in vascular tissues, mesophyll to sieve elements. Cytokinin levels in xylem sap and leaf tissue had been associated with leaf expansion and cell division under nitrogen deprivation. Therefore, increased root mass with increasing nitrogen supply produced higher cytokinin levels leading to higher cell division which contributed in stem girth, number and size of epidermal and photosynthetic cells. The higher cytokinin production by greater root masses and translocation to the shoot might be one of the reasons for larger cell numbers in photosynthetic tissue and enlarged phloem parenchyma transfer cells with significantly developed labyrinths (Palmer et al., 1996; Wagner \& Michael, 1971). Cytokinin activated growth of stem diameter rather than elongation was associated with increased number of vessels, the number of cells in the phloem region (Wagner \& Beck, 1993; Singh et al., 1992; Takei et al., 2001; Sakakibara et al., 2006).

Liposomes originate from the chloroplast membranes with the onset of senescence that is early in case of nitrogen starved leaves than under nitrogen supply. The lipid bodies are converted to sucrose involving interaction of cytosol, glyoxysomes and mitochondria. At the first step proteolysis of membrane protein of liposomes/oleosins is required for degradation of phospholipid monolayer of this organelle by patatin-type phospholipase (Noll et al., 2000). The catabolism of the oxidized lipids in glyoxysomal $\beta$-oxidation provides reducing equivalents and acetyl-CoA for synthetic processes. 13-Lipoxygenase (13-LOX) dependent and independent pathways have been suggested for mobilization of lipids in sunflower (Feussner et al., 2001). 
LOXes produce hydroperoxy fatty acids that are subsequently metabolized to form bioactive compounds such as 12-oxo-phytodienoic acid and jasmonate (Creelman \& Mullet, 1997). An interaction of auxin and jasmonate has been reported in sunflower root growth regulation (Corti Monzón et al., 2012). The cytoplasmic and vacuolar pools of sucrose are suggested to be higher and help in turgor maintenance and early higher expansion rate of leaf area and biomass production in nitrogen stressed leaves. A reduced starch content and increased proportion of sucrose to total sugars may be regarded as increased partitioning to roots of nitrogen stressed plants in comparison to the control (Rufty et al., 1990; Ciompi et al., 1996). Our study also confirms the longer primary root in sunflower under control condition (Figure 1(B)). Nitrogen deficiency leads to sugar accumulation (Kumari, 2011) by decreasing demand of carbon skeletons for amino acids and protein synthesis. Nitrogen-deficiency decreases total assimilation as leaves are shorter-lived, senescing and losing photosynthetic competence more quickly than when it is abundant, due to remobilization of nitrogen to growing organs (Millard \& Catt, 1988; Lawlor et al., 1989; Brouqisse et al., 2001). An early start of senescence can be expected to be favorable for synthesis of chlorophyll, biogenesis of chloroplasts and recycling of nitrogen in the photosynthetic cells in new leaves under low supply of nitrogen. Photosensitization by higher chlorophyll $b$ and destruction of chloroplasts by reactive oxygen species (oxygen free radical, hydroxyl radicals, and singlet oxygen) might be one of the reasons for onset of early senescence in nitrogen starved leaves.

While xanthophyll cycle operates under high irradiance exposed sunflower leaves irrespective of nitrogen supply (Figure 5). Like chlorophyll, $\beta$-carotene in the chloroplast is complexed with protein absorbs strongly in the blue region of the visible spectrum is known to quench triplet excited chlorophyll and highly reactive singlet excited oxygen. Light saturation point of photosynthesis is much reduced by reduction in chloroplast size as a result of nitrogen deprivation. The relative pigments reorganization helps in thermal dissipation processes to overcompensate for the lowered carbon dioxide assimilation capacity at high irradiances leaving photosystem (PS) II much more oxidized than the normal condition. Moreover, the protochlorophyllide on thin layer chromatography shows faster oxidation of chlorophyll in nitrogen deficient leaves. The chlorophyll $\mathrm{a} / \mathrm{b}$ ratio is reduced in fully expanded leaves or remains unaffected at flowering stage in sunflower leaves under nitrogen starvation condition due to the increase in chlorophyll $\mathrm{b}$. Chlorophyll and total soluble protein contents were linked to nitrogen levels, chloroplast membrane organization, cell division activity or new leaves formation, individual leaf expansion, and process of mobilization of various pools of nitrogen from older leaves.

Xylem and phloem are closely aligned in sunflower and it is most likely that rapid xylem to phloem transfer of amino acids occurred from both leaves and stem. Xylem parenchyma cells have been shown to be actively involved in the uptake of amino acids from xylem may also mediate xylem to phloem transfer (Van Bel et al., 1981). Valine and asparagine are readily transferred from xylem to the phloem whereas glutamate and aspartate accumulation in the interveinal region of a legume contributed in the texture change of the leaves with high nitrogen levels. Simultaneous influx and efflux demonstrated by Yoneyama and Sano $(1977,1978)$ suggested that some nitrogen was translocated from the leaves before it could be incorporated into protein and other was translocated only after it had been incorporated into protein. However, $60 \mathrm{~kg} \mathrm{~N} \mathrm{ha}^{-1}$ extended epidermal cell size but number of photosynthetic cells were reduced in comparison to control leaf. Longer leaves and carbon partitioning in cell wall contents has been reported in grasses (Casey et al., 1999). The leaf size and weight relationship may discard the incorporation of nitrogen into protein thereby diverting into the structural components of leaf, cell walls and new cell formation in the lower epidermis to provide the support at the horizontal axis of stem with increasing supply of nitrogen.

\section{Conclusion}

Cell division at the initial phases of growth and expansion in the epidermal cells were linked with leaf expansion rate rather than the duration of the expansion under different levels of nitrogen. Chlorophyll and total soluble protein contents were linked to chloroplast membrane organization, new leaves formation, individual leaf expansion, and process of mobilization of various pools of nitrogen from older leaves at different levels of nitrogen. Nitrogen supply exert developmental control on phloem size and stimulated the translocation of assimilates from chloroplast to the sites of high carbon sink activity i.e. leaves, capitulum/florets/seeds.

\section{References}

Agüera, E., Cabello, P., \& de la Haba, P. (2010). Induction of leaf senescence by low nitrogen nutrition in sunflower (Helianthus annuus) plants. Physiologia Plantarum, 138, 256-67. https://doi.org/10.1111/ j.1399-3054.2009.01336.x

Arnon, D. I. (1949). Copper enzymes in isolated chloroplasts. Polyphenol oxidases in Beta vulgaris. Plant Physiology, 24, 1-15. https://doi.org/10.1104/pp.24.1.1 
Brouqisse, R., Masclaux, C., Feller, U., \& Raymond, P. (2001). Protein hydrolysis and nitrogen remobilization in plant life and senescence. In P. J. Lea, \& J. F. Morot-Gaudry (Eds.), Plant nitrogen (pp. 275-293). Springer-Verlag, Berlin. https://doi.org/10.1007/978-3-662-04064-5_11

Casey, I. A, Brereton, A. J., Laidlaw, A. S., \& McGilloway, D. A. (1999). Effects of sheath tube length on leaf development in perennial ryegrass (Lolium perenne L.). Annals Applied Biology, 134, 251-257. https://doi.org/10.1111/j.1744-7348.1999.tb05261.x

Chapin, F. S. III, Walter, C. H. S., \& Clarkson, D. T. (1988b). Growth response of barley and tomato to nitrogen stress and its control by abscisic acid, water relations, and photosynthesis. Planta, 173, 352-366. https://doi.org/10.1007/BF00401022

Corti Monzón, G., Pinedo, M., Lamattina, L., et al. (2012). Sunflower root growth regulation: The role of jasmonic acid and its relation with auxin. Plant Growth Regulation, 66, 129-136. https://doi.org/10.1007/s10725011-9636-4

Creelman, R. A., \& Mullet, J. E. (1997). Biosynthesis and action of Jasmonates in plants. Annual Review Plant Physiology Plant Molecular Biology, 48, 355-381. https://doi.org/10.1146/annurev.arplant.48.1.355

Evans, J. R., \& Terashima, I. (1987). Effects of nitrogen nutrition on electron transport components and photosynthesis in spinach. Australian Journal Plant Physiology, 14, 281-292. https://doi.org/10.1071/ PP9870059

Feussner, I., Kuhn, H., \& Wasternack, C. (2001). Lipoxygenase-dependent degradation of storage lipids. Trends Plant Science, 6, 268-273. https://doi.org/10.1016/S1360-1385(01)01950-1

Forde, B. G., \& Walch-Liu, P. (2009). Nitrate and Glutamate as environmental cues for behavioral responses in plant roots. Plant Cell Environment, 32, 353-360. https://doi.org/10.1111/j.1365-3040.2008.01927.x

Foyer, C. H., Parry, M., \& Noctor, G. (2003). Markers and signals associated with nitrogen assimilation in higher plants. Journal Experimental Botany, 54, 585-593. https://doi.org/10.1093/jxb/erg053

Gastal, F., \& Lemaire, G. (2002). N uptake and distribution in crops: An agronomical and ecophysiological perspective. Journal Experimental Botany, 53(370), 789-799. https://doi.org/10.1093/jexbot/53.370.789

Gunnino, B. E. S., \& Pate, J. S. (1969). "Transfer cells" plant cells with wall ingrowths, specialized in relation to short distance transport of solutes-Their occurrence, structure, and development. Protoplasma, 6, 107-133. https://doi.org/10.1007/BF01247900

Hak, R., Rinderle-Zimmer, U., Lichtenthaler, H. K., \& Natr, L. (1993). Chlorophyll a fluorescence signatures of nitrogen deficient barley leaves. Photosynthetica, 28, 151-159.

Haritatos, E., Medville, R., \& Turgeon, R. (2000). Minor vein structure and sugar transport in Arabidopsis thaliana. Planta, 211, 105-111. https://doi.org/10.1007/s004250000268

Hunt, E. R., Weber, J. A., \& Gates, D. M. (1985). Effects of nitrate application on Amaranthus powelli WATS. III. Optimal allocation of leaf nitrogen for photosynthesis and stomatal conductance. Plant Physiology, 79, 619-624. https://doi.org/10.1104/pp.79.3.619

Jovanovic, Z., Djakovic, T., Stikic, R., et al. (2004). Effect of nitrogen deficiency on leaf growth, cell wall peroxidase activity in contrasting maize genotypes. Plant and Soil, 265, 211-223. https://doi.org/10.1007/ s11104-005-0503-9

Khamis, S., Lamaze, T., Lemoine, Y., \& Foyer, C. (1990). Adaptation of the photosynthetic apparatus in maize leaves as a result of nitrogen limitation. Plant Physiology, 94, 1436-1443. https://doi.org/10.1104/ pp.94.3.1436

Lawlor, D. W., Kontturi, M., \& Young, A. T. (1989). Photosynthesis by flag leaves of wheat in relation to protein, ribulose bisphosphate carboxylase activity and nitrogen supply. Journal Experimental Botany, 40, 43-52. https://doi.org/10.1093/jxb/40.1.43

MacAdam, J. W., Volenec, J. J., \& Nelson, C. J. (1989). Effect of nitrogen on mesophyll cell division and epidermal cell elongation in tall fescue leaf blades. Plant Physiology, 89, 549-556. https://doi.org/10.1104/ pp.89.2.549

Maksymowych, R. (1973). Analysis of leaf development. Cambridge University Press. 
Millard, P., \& Catt, J. W. (1988). The influence of nitrogen supply on the use of nitrate and ribulose 1, 5-bisphosphate carboxylase/oxygenase as leaf nitrogen stores for growth of potato tubers (Solanum tuberosum L.). Journal Experimental Botany, 39, 1-11. https://doi.org/10.1093/jxb/39.1.1

Noll, F., May, C., \& Kindl, H. (2000). Phospholipid monolayer of plant lipid bodies attacked by phospholipase A2 shows $80 \mathrm{~nm}$ holes analysed by atomic force microscopy. Biophysical Chemistry, 86, 29-35. https://doi.org/10.1016/S0301-4622(00)00156-3

Ourry, A., MacDuff, J., Volenec, J. J., \& Gaudillère, J. P. (2001). Nitrogen Traffic during Plant Growth and Development. In P. J. Lea, \& J. F. Morot-Gaudry (Eds.), Plant nitrogen (pp. 255-273). Springer-Verlag, Berlin. https://doi.org/10.1007/978-3-662-04064-5_10

Palmer, S. J., Berridge, D. M., McDonald, A. J. S., \& Davies, W. J. (1996). Control of leaf expansion in sunflower (Helianthus Annuus L.) by nitrogen nutrition. Journal Experimental Botany, 47, 359-368. https://doi.org/10.1093/jxb/47.3.359

Paul, M. J., \& Foyer, C. H. (2001). Sink regulation of photosynthesis. Journal Experimental Botany, 52, 1383-1400. https://doi.org/10.1093/jexbot/52.360.1383

Radin, J. W., \& Boyer, J. S. (1982). Control of leaf expansion by nitrogen nutrition in sunflower plants. Role of hydraulic conductivity and turgor. Plant Physiology, 69, 771-775. https://doi.org/10.1104/pp.69.4.771

Sage, R. F., \& Pearcy, R. W. (1987). The nitrogen use efficiency of $C_{3}$ and $C_{4}$ plants. II. Leaf nitrogen, effects on the gas exchange characteristics of Chenopodium album (L.) and Amaranthus retroflexus (L.). Plant Physiol., 84, 959-963. https://doi.org/10.1104/pp.84.3.959

Sakakibara, H., Takei, K., \& Hirose, N. (2006). Interaction between nitrogen and cytokinin in the regulation of metabolism and development. Trends Plant Science, 11, 440-448. https://doi.org/10.1016/j.tplants.2006. 07.004

Singh, S., Letha, D. S., Zhang, R., \& Palni, L. M. S. (1992). Cytokinin biochemistry in relation to leaf senescence: IV. Effect of nitrogenous nutrient on cytokinin levels and senescence of tobacco leaves. Physiologia Plantarum, 84, 262-268. https://doi.org/10.1111/j.1399-3054.1992.tb04663.x

Steer, B. T., Hocking, P. J., Kortt, A. A., \& Roxburgh, C. M. (1984). Nitrogen nutrition of sunflower (Helianthus annuus L.): yield components, the timing of their establishment and seed characteristics in response to nitrogen supply. Field Crop Research, 9, 219-236. https://doi.org/10.1016/0378-4290(84)90028-5

Sugiharto, B., Miyata, K., Nakamoto, H., et al. (1990). Regulation of expression of carbon assimilating enzymes by nitrogen in maize leaf. Plant Physiology, 92, 963-969. https://doi.org/10.1104/pp.92.4.963

Takei, K., Sakakibara, H., Taniguchi, M., \& Sugiyama, T. (2001). Nitrogen dependent accumulation of cytokinins in root and the translocation to leaf; implication of cytokinin species that induces gene expression of maize response regulator. Plant Cell Physiology, 42, 85-93. https://doi.org/10.1093/pcp/ pce009

Van Bel, A. J. E., Van Leeuwenkamp, P., \& Van der Schoot, C. (1981). Amino acid uptake by various tissues of the tomato plant. Effects of external $\mathrm{pH}$ and Light. Journal Pflanzenphysiol, 104, 117-128. https://doi.org/10.1016/S0044-328X(81)80017-7

Vos, J., \& Biemond, H. (1992). Effect of nitrogen on the development and growth of the potato plant. I. leaf appearances, expansion growth, life span of leaves and stem branching. Annals Botany, 70, 27-35. https://doi.org/10.1093/oxfordjournals.aob.a088435

Wagner, B. M., \& Beck, E. (1993). Cytokinins in the perennial herb Urtica dioica L. as influenced by its nitrogen status. Planta, 190, 511-518. https://doi.org/10.1007/BF00224790

Wagner, V. H., \& Michael, G. (1971). The influence of varied nitrogen supply on the production of cytokinins in the roots of sunflower plants. Biochem Physiol Pflanzen, 162, 147-158.

Yoneyama, T., \& Sano, C. (1978). Nitrogen nutrition and growth of the rice plant. II. Considerations concerning the dynamics of nitrogen in rice seedlings. Soil Science Plant Nutrition, 24, 191-198. https://doi.org/ 10.1080/00380768.1978.10433095

Zhuo, D., Okamoto, M., Vidmar, J. J., \& Glass, A. D. (1999). Regulation of a putative high-affinity nitrate transporter (Nrt2; 1At) in roots of Arabidopsis thaliana. The Plant Journal, 17, 563-568. https://doi.org/ 10.1046/j.1365-313X.1999.00396.x 


\section{Copyrights}

Copyright for this article is retained by the author(s), with first publication rights granted to the journal.

This is an open-access article distributed under the terms and conditions of the Creative Commons Attribution license (http://creativecommons.org/licenses/by/4.0/). 